\title{
Pendekatan Tradisionalis dan Revisionis dalam Kajian Sejarah Pembentukan Al-Qur'ān dan Tafsir pada Masa Islam Awal
}

\author{
Yusuf Rahman ${ }^{1}$
}

\begin{abstract}
Western scholars are still debating and proposing different - and sometimes conflicting -- theories on the history of Qur'anic text and tafsir in early Islam. These differences are based on their different attitudes towards Muslim sources, which according to some of them are not historical sources, since they are written decades after the event. In addition, there are contradictory traditions surrounding the event in the sources. Acknowledging the problems in these sources, there are some Western scholars who radically doubt the historicity of these sources and would not use them in their reconstruction of the history of early Islam, but there are others who accept them as they are provided that there is no any historical evidence which argues against the available Muslim sources.

This article discusses the work of Mun'im Sirry entitledKontroversi Islam Awal, especially that which is related with the study of the Qur'ān and tafsir.
\end{abstract}

\begin{abstract}
Abstrak
Para sarjana Barat masih berdebat dan mengajukan teori yang berbeda - bahkan berlawanan -- tentang sejarah teks al-Qur'ān dan tafsir pada masa Islam Awal. Perbedaan ini disebabkan pada perbedaan sikap mereka terhadap sumber-sumber Muslim, yang bagi sebagian mereka bukanlah merupakan sumber historis, karena ditulis beberapa dekade setelah suatu peristiwa terjadi. Di samping itu, terdapat banyak kontradiksi dalam riwayat-riwayat yang menceritakan suatu peristiwa dalam sumber tersebut. Mengakui adanya masalah dalam sumber-sumber tersebut, sarjana Barat ada yang secara radikal menyangsikan kesejarahan sumber tersebut dan tidak mau menggunakannya dalam merekonstruksi sejarah Islam Awal, namun ada pula yang menerimanya as it is
\end{abstract}

${ }^{1}$ Dosen Fakultas Ushuluddin dan Sekolah Pascasarjana UIN Syarif Hidayatullah Jakarta. E-mail: yusuf.rahman@uinjkt.ac.id 
selama belum ada bukti historis yang membantah sumber yang ada.

Tulisan ini mendiskusikan karya Mun'im Sirry yang berjudul Kontroversi Islam Awal, terutama terkait dengan kajian al-Qur'ān dan tafsir.

Keywords: Pendekatan revisionis dan tradisionalis, sumber Muslim, Islam Awal, respon akademik kritis dan respon teologispolemis.

\section{Pendahuluan}

“The Orientalist enterprise of Qur' anic studies, whatever its other merits and services, was a project born of spite, bred in frustration and nourished by vengeance: the spite of powerful for the powerless, the frustration of the 'rational' towards the 'superstitious' and the vengeance of the 'orthodox' against the 'non-conformist'."'

Demikianlah Parvez Manzoor menulis mengkritisi karya-karya Sarjana non-Muslim Barat yang menulis tentang kajian al-Qur'an. Ia melihat karyakarya tersebut didominasi dengan sikap skeptisisme, yaitu tidak mempercayai apapun yang sudah diterima umat Islam.

Tapi apakah Manzoor telah jujur membaca seluruh kesarjanaan Barat tentang al-Qur'ān dan tafsir. ${ }^{3}$ Sayangnya, sikap antipati dan reaksi negatif ini tidak hanya disuarakan oleh Manzoor. Beberapa sarjana Muslim lainnya juga memiliki sikap reaksioner yang sama. Di Indonesia, misalnya, para peneliti INSISTS (Institute for the Study of Islamic Thought and Civilizations) mengkritisi dengan "membabi buta" kesarjanaan Barat dengan alasan bahwa mereka memiliki hidden agenda untuk menghancurkan Islam. Mereka mewanti-

\footnotetext{
${ }^{2}$ Manzoor "Method Against Truth: Orientalism and Qur'anic Studies," Muslim World Book Review 7 (1987), 33-49. Dicetak ulang di Andrew Rippin (ed.) The Qur'an: Style and Content (Aldershot, Singapore, Sydney: Ashgate Variorum, 2001), 381-397. Kutipan dari 381.

${ }^{3}$ Penting dicatat bahwa Manzoor mensurvei karya-karya sarjana Barat tentang kajian al-Qur'àn hingga tahun 1987, masa di mana kajian "akademik" kritis terhadap alQur'an sedang mulai berkembang, terutama dengan penerbitan karya Wansbrough dan Burton. Lihat daftar buku dan artikel yang dirujuk Manzoor.
} 
wanti bahwa kesarjanaan Barat didominasi oleh pandangan dunia (worldview) sekuler yang bertentangan dengan pandangan dunia Islami. ${ }^{4}$

Dalam konteks inilah, penulis melihat letak pentingnya karya Mun'im Sirry yang berjudul Kontroversi Islam Awal: Antara Mazhab Tradisionalis dan Revisionis. ${ }^{5}$ Pertama, kajian Sarjana Barat terhadap al-Qur'ān dan tafsìr sangat kaya, bervariasi dan terus berkembang. Kajian mereka mencakup tidak hanya sejarah pembentukan al-Qur'ān dan tafsir pada masa awal, akan tetapi juga tentang tema-tema dan doktrin yang ada dalam al-Qur'ān, struktur dan gaya bahasa al-Qur'ān, berbagai teori dan prosedur penafsiran, tafsir klasik, pertengahan dan modern, dll. ${ }^{6}$ Yang lebih penting untuk ditekankan dari kajian sarjana Barat ini, menurut Sirry, adalahbahwa sikap skeptik radikal beberapa sarjana Barat terhadap sumber literatur "Islam," lebih terfokus kepada sumber Muslim yang terkait dengan Islam Awal, yaitu masa pembentukan Islam pada masa awal. Banyak sarjana Barat yang mempermasalahkan sumber Islam Awal - yang dalam istilah Sirry "sumber masalah masalah sumber." Selain sarjana Barat yang memiliki pandangan yang revisionis radikal, juga terdapat sarjana yang bermazhab tradisionalis dalam menyikapi sumber literatur tersebut, dan juga ada sarjana yang mengambil jalan tengah, di antara revisionis radikal dan tradisionalis.

\section{Kesarjanaan Barat dalam Kajian Sarjana Indonesia}

Karya akademik yang mengkaji dan merespon kesarjanaan Barat dalam kajian Islam, terutama lagi dalam kajian al-Qur'ān dan tafsìr, telah lama vakum di Indonesia. Beberapa dekade sebelumnya Taufik Adnan Amal, dosen IAIN (sekarang UIN) Makassar, menulis secara akademikRekonstruksi Sejarah AlQur'an, ${ }^{8}$ yang menggambarkan problematika penulisan dan kodifikasi al-Qur'an dengan merujuk kepada sumber-sumber tradisional Muslim dan membandingkannya dengan pandangan sarjana Muslim dan Barat. Namun, kebanyakan karya sarjana Muslim di Indonesia dalam merespon kajian sarjana

\footnotetext{
${ }^{4}$ Syamsuddin Arif, Orientalis \& Diabolisme Pemikiran (Jakarta: GIP, 2008), 23.
} Lihat juga Hamid Fahmi Zarkasyi, "Worlview Islam dan Kapitalisme Barat," Jurnal Tsaqafah 9, 1 (2013): 15-36.

${ }^{5}$ Lihat Sirry, Kontroversi Islam Awal: Antara Mazhab Tradisionalis dan Revisionis (Bandung: Mizan, 2015).

${ }^{6}$ Lihat, misalnya, kumpulan tulisan karya-karya sarjana Barat dalam kajian alQur'ān dan tafsir, Colin Turner, The Koran: Critical Concepts in Islamic Studies (London dan New York: Routledge, 2004), 4 jilid, dan Mustafa Shah, Tafsir: Interpreting the Qur'ann (London dan New York: Routledge, 2013), 4 jilid.

${ }^{7}$ Lihat Sirry, Kontroversi Islam Awal, Bab 1, terutama 21 dst.

${ }^{8}$ Yogyakarta: Forum Kajian Budaya dan Agama (FKBA), 2001. 
Barat lebih bersifat teologis dan polemis. Mereka ditulis bukan dalam kerangka akademik, dan bukan diperuntukkan kepada masyarakat akademik, yang memiliki latar belakang agama berbeda atau bahkan mungkin tidak beragama. Kebanyakan karya-karya ini ditulis secara teologis "oleh orang Islam untuk orang Islam,"dan untuk menunjukkan "bahaya" kajian non Muslim. Tidak mengherankan jika keluar dalil ayat wa lan tarḍa 'anka l-Yahūdu wa lā n-nașārā ḩattā tattabi'a millatahum(Q. 2:120) ${ }^{9}$ ketika mereka merespon karya sarjana Barat.

Kita masih ingat tentunya polemik antara Adnin Armas (saat itu mahasiswa S3 di ISTAC dan kini Direktur INSISTS) dengan Sirry (saat itu mahasiswa S3 di UCLA, dan kini dosen di University of Notre Dame, AS) di Koran nasional Republika pada tahun 2005 di sekitar peluncuran buku terjemahan bahasa Indonesia The History of the Qur'anic Text karya Muhammad Mustafa Azami. Saat itu Armas menyambut kedatangan Azami di Indonesia dan juga peluncuran buku bahasa Indonesianya sebagai Pembela alQur'an dari kritikan Orientalis. ${ }^{10}$ Azami memang dikenal sebagai sarjana Muslim yang mengkritik J. Schacht dan Orientalis lainnya dalam kajian hadis.

Namun bagi Sirry, yang telah "melahap" karya-karya sarjana Barat dalam kajian al-Qur'an, Azami telah gagal dalam karyanya untuk merujuk kepada karya-karya sarjana Barat yang cukup "simpatik" terhadap al-Qur'an, seperti W.M. Watt, A. Welch, K. Cragg, D. Madigan, dan lain-lain. ${ }^{11}$ Akan tetapi kritikan Sirry ini direspon Armas dengan sangat simplistik dan juga dengan nada merendahkan karya-karya mereka dengan mengungkapkan bahwa para sarjana tersebut "tidak pakar" dalam kajian al-Qur'an. ${ }^{12}$ Perlu dipertanyakan kepada Armas apa yang dimaksud dengan "pakar" di sini. Apakah sarjana-sarjana Barat yang "simpatik" terhadap al-Qur'ān dan telah menulis beberapa karya penting tentang al-Qur'ān dan tafsir tersebut tidak bisa dikategorikan sebagai "pakar" dalam kajian al-Qur'ān.

Sirry sendiri telah menjawab respon Armas tersebut, namun opininya tidak diterbitkan Republika - for no explicit reason -- namun akhirnya jawaban tersebut dibagikan di mailing list - dengan judul “Antara Fakar dan Kafar dalam

${ }^{9}$ Arif, Orientalis \& Diabolisme Pemikiran, 21. Dengarkan juga presentasi lisannya tentang "The Challenge of Orientalist in Islamic Thought" di the International Institute of Islamic Thought and Civilization (ISTAC) bulan Mei 2010 yang juga bisa diakses di youtube https://www.youtube.com/watch?v=QZW7Z1UH7L0, yang secara eksplist menyatakan bahwa karyanya ditulis oleh orang Islam dan untuk orang Islam.

${ }^{10}$ Armas, "Selamat Datang Profesor Azami!," Republika 30 March 2005.

${ }^{11}$ Sirry, "Rekonstruksi Sejarah Teks Alquran," Republika 1 April 2005.

12 Armas, "Orientalis dan Studi Alquran," Republika 14 April 2005. 
Kajian Alquran." Sebagaimana diketahui bahwa huruf-huruf dalam kata berbahasa Arab bisa dipindah-pindah (tașrif) namun masih memiliki arti. Dalam hal ini kata Fakar, yang terdiri dari huruf fa, ka, ra, yang berarti berfikir, yang kemudian menjadi, pakar, bisa diubah peletakannya menjadi $\mathrm{ka}, \mathrm{fa}, \mathrm{ra}$, yaitu kafir. Dengan artikel ini, Sirry ingin mengatakan bahwa Armas dan yang lainnya yang menentang kajian Barat terhadap al-Qur'ān dan tafsīr bukan karena alasan para sarjana ini tidak fakar/pakar akan tetapi karena mereka kafar/kafir! Dengan demikian, apapun yang dikatakan sarjana Barat tentang alQur'ān dan tafsir, selama mereka masih kafir, tidak bisa diterima.

Sikap seperti ini tentu saja sangat teologis: menilai karya berdasarkan keimanan seseorang, bukan atas dasar kekuatan dan kedalaman argumentasi dan metode.Ini sangat berbeda dengan karya Sirry yang berjudul Kontroversi Islam Awal yang secara akademik mensurvei perdebatan kajian sarjana tentang Islam Awal serta mengkritisi beberapa teori dan kesimpulan sarjana tersebut. Selain buku ini, Sirry sebelumnya telah menerbitkan pada tahun 2013 buku yang terkait dengan kajian al-Qur'ān yang berjudul Polemik Kitab Suci: Tafsir Reformis atas Kritik al-Qur'an terhadap Agama Lain, ${ }^{13}$ dan saat ini sedang mempersiapkan penerbitan bukunya yang ketiga, dalam kajian al-Qur'ān yang berbahasa Indonesia, berjudul Tradisi Intelektual Islam.

\section{Sikap Kritis terhadap Sumber Literatur Muslim tentang Islam Awal}

Mengawali bukunya, Sirry menulis:

"Buku ini ditulis tidak untuk meragukan apalagi mengubah keyakinan anda, pembaca, melainkan untuk membuka berbagai kemungkinan dalam memahami Islam dan menganalisis proses kemunculannya ke atas panggung sejarah. Namun demikian, jika anda termasuk pembaca yang akan tersinggung manakala pemahaman konvensional anda dipertanyakan, maka saya anjurkan untuk tidak membaca buku ini. Saya juga tidak menganjurkan buku ini bagi mereka yang akan menelan mentahmentah setiap informasi dan analisis at face value. Sejujurnya, saya tidak khawatir bahwa buku ini akan kehilangan pembaca, karena kedua model pembaca di atas tidaklah signifikan dari segi jumlah, kalaupun ada. Tujuan buku ini ialah menstimulasi 'the right question', walaupun mungkin kita tidak bersepakat tentang jawabannya." 14

${ }^{13}$ Sirry, Polemik Kitab Suci: Tafsir Reformis atas Kritik Al-Qur'an terhadap Agama Lain (Jakarta: Gramedia, 2013).

${ }^{14}$ Sirry, Kontroversi Islam Awal, 9. 
Inilah warning yang diajukan Sirry kepada para pembacanya yang pastinya akansangat terkejut dengan pembahasan di dalam buku ini, karena yang didiskusikan adalah sesuatu yang sudah secara normatif diterima secara final oleh kebanyakan umat Islam. Namun, bagi Sirry, jika dibaca secara kritis historis beberapa yang sudah "mapan" tersebut, ternyata tidak berdiri di atas fondasi sumber yang bisa dipertanggungjawabkan secara historis. Oleh karena itu, "[b]uku ini," Sirry melanjutkan, "ditulis oleh seseorang yang mempertanyakan hal-hal yang dianggap mapan dan ditujukan kepada pembaca yang menganggap pertanyaan atas hal-hal mapan sebagai sesuatu yang absah dan halal."15

Pernyataan yang sangat berani ini menunjukkan sikap kritis akademis Sirry terhadap keyakinan agamanya. Walaupun sebagai "insider" (orang dalam) dan "believer" (orang yang beriman), Sirry tetap dapat bersikap kritis terhadap tradisi yang selama ini sudah tertanam dalam sejarah intelektual Islam. Pada saat yang sama, pernyataan ini juga untuk membantah pandangan gurunya dan pembimbingnya Prof. Fred Donner dalam artikelnya yang berjudul "The Historian, the Believer, and the Qur'an," "yang menyangsikan bahwa seorang Muslim bisa sungguh-sungguh menjadi sejarawan Islam Awal, karena sejarawan "lebih berkomitmen untuk menggunakan kaidah-kaidah logis dan saintifik dalam menyelesaikan problem-problem intelektual." ${ }^{17}$ Demikian pula sejarawan tidak bisa menerima hal-hal yang luar biasa, seperti mukjizat, sebagai fakta historis. Hal ini berbeda dengan pandangan orang beriman yang meyakini dan menerima hal-hal yang luar biasa.

Akan tetapi bagi Sirry, sebagai seorang yang beriman, sikap kritis terhadap keyakinan konvensional dan tradisional tersebut tidak membuat seseorang menjadi tidak beriman. Ia menunjukkan contoh beberapa sarjana Muslim yang kritis terhadap agamanya, seperti Abdulkarim Suroush, Fazlur Rahman, dll. Selain itu ia juga menunjukkan bahwa "kaum beriman tidak memiliki pemahaman tunggal"18 tentang berbagai isu keyakinan agama. Mereka memiliki pemahaman yang berbeda, yang kemudian melahirkan mazhabmazhab pemikiran dalam teologi, tasawuf dan juga fikih. Walaupun saya harus tambahkan di sini bahwa sikap kritis seperti ini masih sering tidak diterima oleh kebanyakan kaum Muslim.

${ }^{15}$ Sirry, Kontroversi Islam Awal, 10.

16 Donner, "The Historian, the Believer, and the Qur'ān," dalam New Perspectives on the Qur'an, ed. Gabriel Said Reynolds (London: Routledge, 2011).

${ }^{17}$ Lihat ringkasan argumentasi Donner di Sirry, Kontroversi Islam Awal, 69-70.

${ }^{18}$ Sirry, Kontroversi Islam Awal, 70-71. 
Yang dimaksudkan dengan Islam Awal dalam buku ini adalah Islam pada masa pembentukan awalnya, yang terdiri dari sejarah kehidupan Nabi, sejarah al-Qur'an, dan sejarah ekspansi Islam. Yang menjadi “masalah" dari Islam Awal ini adalah bahwa sejarahnya didasarkan pada sumber-sumber yang bermasalah, karena sumber-sumber yang ada tentang biografi Nabi, sejarah al-Qur'an dan ekspansi Islam, "ditulis beberapa abad setelah kejadian yang direkamnya." ${ }^{19}$ Sirry, misalnya menunjukkan bahwa kitab-kitab sirah Nabi dan sejarah Islamditulis antara tahun 750-800 Masehi, yang berarti beberapa generasi setelah wafatnya Nabi Muhammad saw. Ibn Ishạq, misalnya, yang atasnya kita merujuk biografi Nabi, wafat pada 150 H/767 M, dan Ibn Hishām yang menghimpun karya Ibn Ishạā wafat pada 218 H/833 M.

Demikian juga dengan isnād yang diasumsikan dapat menjamin keotentikan suatu riwayat, namun, sebagaimana yang sudah ditunjukkan beberapa sarjana, praktek penggunaan isnād baru berkembang di awal abad kedua hijriyyah, untuk memverifikasi transmisi riwayat-riwayat yang diketahui terdapat kebohongan dan pemalsuan.

Selain ditulis belakangan, beberapa narasi yang ada dalam sumber tersebut mengandung banyak kontradiksi. ${ }^{20}$ Hal ini karena memang narasinarasi tersebut ditulis belakangan - lama setelah persitiwa itu terjadi. Pilihan para sarjana dalam menghadapi kontradiksi narasi ini adalah memverifikasi mana narasi yang faktual dan yang tidak faktual, jika memungkinkan, atau meragukan sama sekali kejadian persitiwa tersebut.

Oleh karena permasalahan sumber inilah para sarjana Barat berbeda pendapat dalam menyikapi sumber utama ini. Merujuk kepada pandangan gurunya Fred Donner dalam bukunya Narratives of Islamic Origins, ${ }^{21}$ Sirry membagi pendekatan sarjana Barat terhadap sumber ini kepada empat pendekatan. Pertama pendekatan deskriptif tradisional, yaitu pendekatan yang tidak mempersoalkan informasi yang disampaikan sumber-sumber Muslim yang kenyataannya ditulis belakangan. Sarjana Barat yang masuk dalam ketegori ini adalah Hodgson dengan bukunya The Venture of Islam, Ira Lapidus dengan $A$ History of Islamic Societies, Hugh Kennedy Muhammad and the Age of Caliphate, dll. Buku-buku ini sama sekali tidak mempersoalkan historisitas sumber-sumber yang ditulis ulama Muslim.

${ }^{19}$ Sirry, Kontroversi Islam Awal, 14.

${ }^{20}$ Sirry, Kontroversi Islam Awal, 15.

${ }^{21}$ Sirry, Kontroversi Islam Awal, 39ff. Untuk lengkapnya, lihat juga Fred M. Donner, Narratives of Islamic Origins: The Beginnings of Islamic Historical Writing (Princeton, NJ: The Darwin Press, 1998), 5-25. 
Berbeda dengan pendekatan deskriptif, ada beberapa sarjana Barat yang secara radikal mempertanyakan sumber-sumber Muslim.Mereka dikategorikan dengan pendekatan skeptis radikal. Kelompok ini menolak sama sekali informasi yang terdapat dalam karya-karya ulama Muslim. Bagi mereka "kitabkitab sirah atau sejarah itu ditulis dengan motif kecintaan dan pengagungan terhadap Nabi Muhammad dan periode-periode awal yang dianggapnya "zaman emas." ${ }^{22}$ Sejarah yang ditulis oleh ulama Muslim, menurut pandangan mereka, lebih pas dikategorikan sebagai "salvation history" (sejarah penyelamatan), karena merefleksikan apa yang penulis-penulis Muslim "believe/assume have happened", bukan yang sebenarnya terjadi "what have really happened." Proses kanonisasi al-Qur'an, misalnya, tidak terjadi pada abad pertama, akan tetapi pada abad kedua hijriah, karena tidak ada bukti historis yang netral, selain sumber-sumber Muslim, yang mendukung.

Tokoh utama dari pendekatan ini adalah John Wansbrough dengan dua bukunya Quranic Studies dan Sectarian Milieu. Pengaruh Wansbrough sangat besar terhadap karya-karya sarjana lainnya, seperti Patricia Crone, G.R. Hawting, serta Andrew Rippin. Kelompok skeptis radikal ini mengajukan pertanyaan: "[B]ukti apa yang kita miliki yang mendukung penjelasan tradisionil tentang kodifikasi al-Qur'an dan permulaan Islam? Apakah kita punya bukti-bukti netral yang tidak sarat muatan kepentingan keagamaan yang dapat menjelaskan bagaimana agama ini muncul?"23

Sebagai pengganti sumber-sumber tradisional Muslim yang problematis, para sarjana ini menggunakan sumber-sumber yang ditulis non-Muslim, yang diklaim sezaman atau berdekatan dengan periode Nabi Muhammad, yang ditulis dalam bahasa Suryani atau Yunani, dan merespon kemunculan Islam. Selain itu, mereka juga merujuk kepada data-data arkeologis dan numismatik, seperti uang koin yang ditemukan di beberapa daerah kekuasaan Islam, yang dapat digunakan untuk merekonstruksi sejarah Islam Awal. Walaupun data-data ini masih terbatas, -- apalagi penguasa Saudi Arabia melarang setiap usaha ekskavasi arkeologis di wilayahnya - "data-data ini diyakini lebih awal ketimbang kitab-kitab yang ditulis oleh ulama Muslim."24

Selain kedua pendekatan deskriptif tradisionalis dan revisionis skeptis radikal, terdapat dua pendekatan lagi, yang disebut oleh Sirry sebagai "jalan tengah," karena kedua pendekatan ini tidak secara keseluruhan menerima begitu saja sumber tradisional Muslim atau bahkan menolak secara radikal sumber

\footnotetext{
${ }^{22}$ Sirry, Kontroversi Islam Awal, 50.

${ }^{23}$ Sirry, Kontroversi Islam Awal, 53.

${ }^{24}$ Sirry, Kontroversi Islam Awal, 35.
} 
tradisional tersebut. Pendekatan ketiga adalah pendekatan kritik sumber, yang mengakui bahwa sumber-sumber Muslim memiliki data-data historis. Akan tetapi data-data tersebut telah bercampur dengan bahan yang tidak dapat dipercaya ketika dalam proses transmisi, sehingga banyak ditemukan narasi yang kontradiktif dalam sumber tersebut. Untuk itu, pendekatan ini menawarkan kritik sumber, yaitu "memverifikasi inti historis dalam sumbersumber Muslim tradisional dengan membandingkannya dengan sumber-sumber non Muslim, ataupun dengan mengurai benang kusut dalam narasi-narasi yang bertentangan itu." 25 Sarjana yang menggunakan pendekatan ini, di antaranya Fuat Sezgin dengan bukunya Geschichte des Arabischen Schriftums dan Nabia Abbott Studies in Arabic Literary Papyri.

Pendekatan yang keempat adalah pendekatan kritik tradisi. Pendekatan ini fokus pada aspek periwayatan dan bagaimana suatu informasi ditransmisikan dari suatu generasi ke generasi berikutnya. Jika pendekatan sebelumnya lebih fokus kepada bahan-bahan tertulis, maka pendekatan ini didasarkan pada transmisi lisan. Sarjana Barat yang pertama kali memfokuskan pada pendekatan ini adalah I. Goldziher yang meneliti transmisi hadis-hadis politik dalam kitab hadis, dan dilanjutkan oleh Joseph Scahcht dalam kajiannya tentang hadis-hadis hukum.

Sirry dan beberapa Sarjana Barat dalam hal ini lebih memilih jalan tengah, yaitu pendekatan kritik sumber dan kritik tradisi. Pendekatan ini dipilih, karena, bagi mereka, "sumber-sumber Muslim tidak seyogyanya dicampakkan begitu saja hanya karena informasi-informasi yang disajikannya itu telah terkontaminasi oleh dogma-dogma yang muncul belakangan." 26 Dengan menggunakan pendekatan kritik sumber dan kritik tradisi, diharapkan dapat menghasilkan narasi yang lebih dekat kepada yang sesungguhnya telah terjadi. Sirry, misalnya, menerapkan pendekatan tersebut ketika mendiskusikan makna hanif.Berbeda dengan pendekatan tradisionalis yang memaknainya sebagai "muslim," dan pendekatan revisionis yang memaknainya sebagai "orang musyrik" karena terma tersebut berasal dari Bahasa Aramaik yang berarti "penyembah berhala," Sirry, setelah mengumpulkan data dari al-Qur'ān dan literatur tafsir, berpendapat bahwa makna "ḥanifo" dalam al-Qur'ān tidaklah begitu jelas, begitu juga dalam kitab-kitab tafsir maknanya masih beragam.

\footnotetext{
${ }^{25}$ Sirry, Kontroversi Islam Awal, 43-45.

${ }^{26}$ Sirry, Kontroversi Islam Awal, 63.
} 
"Baru pada periode Ibn Katsir (abad ketujuh H/dua belas M) makna hanif menjadi stabil dan dipersamakan dengan Muslim sendiri." 27

Demikianlah perbedaan pendekatan yang digunakan sarjana Barat dalam menyikapi sumber-sumber tradisional Muslim "yang bermasalah." Bisa dikatakan bahwa kesimpulan yang diperoleh sangat dipengaruhi oleh pendekatan yang digunakan.

\section{Beberapa Tesis Terkait Sejarah Pembentukan al-Qur'ān}

Di dalam bukunya, Sirry mendiskusikan beberapa tesis dan teori sarjana Barat terkait dengan teori kemunculan Islam (Bab Kedua), sejarah al-Qur'ān pada masa Awal Islam (Bab Ketiga), biografi Nabi Muhammad (Bab Keempat), dan sejarah ekspansi kekuasaan Islam (Bab Kelima). Tulisan di bawah ini lebih spesifik mendiskusikan pandangan sarjana Barat tentang sejarah al-Qur'ān pada masa formatif.

Di awal setiap pembahasannya, Sirry selalu memulai dengan penjelasan tradisional sebagaimana yang terdapat dalam sumber-sumber Muslim tradisional, selanjutnya didiskusikan sikap sarjana - baik yang tradisional maupun yang revisionis radikal, dan juga yang menempuh jalan tengah terhadap sumber-sumber tersebut dan kesimpulan yang diperoleh.

Terkait dengan sejarah al-Qur'ān pada masa formatif, tema-tema yang dibahas Sirry adalah sejarah kanonisasi al-Qur'ān, transformasi muṣhaf alQur'ān dari Scriptio Defectiva ke Scriptio Plena, narasi biblikal dalam alQur'ān, kronologi al-Qur'ān, dan asbāb al-nuzūl.

Tentang sejarah kanonisasi al-Qur'ān, jika pandangan tradisional menyatakan bahwa al-Qur'ān dikanonisasi pada masa khalifah 'Uthmān, John Burton dalam bukunya The Collection of the Qur'an berkesimpulan bahwa alQur'ān yang sekarang ada berasal dari muṣhaf Muhammad, bukan muṣhaf 'Uthmān. Kesimpulan ini berdasarkan pada kajiannya terhadap sumber-sumber tradisional Muslim, seperti al-Itqānkarya al-Suyūṭi, al-Maṣāhif karya alSijistāni, al-Burhān karya al-Zarkashi. Burton berkesimpulan, sebagaimana diringkas Sirry,

"semua riwayat tentang pengumpulan al-Qur'an setelah wafatnya Nabi tersebut merupakan suatu konstruk hipotesis fiktif untuk mendukung suatu argumen yuridis. Yakni, argumen bahwa alQur'an merupakan sumber hukum tertinggi kemudian diikuti dengan sunnah. Masalahnya muncul ketika ketentuan hukum al-

${ }^{27}$ Sirry, Kontroversi Islam Awal, 64. Untuk lebih detail diskusi tentang ini, lihat Sirry, "The Early Development of the Quranic Hanif," Journal of Semitic Studies LVI, 2 (Autumn 2011): 345-366. 
Qur'an tidak sejalan dengan hukum yang sudah diterima secara universal ....[m]aka para fuqaha mengembangkan suatu teori abrogasi atau naskh, yang salah satunya berimplikasi bahwa hukum ... tetap berlaku walaupun teksnya tidak lagi ada dalam mushaf al-Qur'an."28

Berbeda dengan Burton, John Wansbrough berkesimpulan bahwa alQur'an baru dibakukan seratus tahun setelah wafatnya Nabi Muhammad. Hal ini disebabkan karena proses kanonisasi al-Qur'ān terjadi beriringan dengan proses formasi komunitas Muslim yang juga terbentuk secara bertahap. Menurut Wansbrough, sebagaimana yang disarikan oleh Gabriel Said Reynolds, kanonisasi al-Qur'ān sebagai scripture adalah merupakan "response to a sectarian environment where Christians and Jews, not pagans, challenged the young Arab religion. In other words, it was in 'Abbasid Iraq that Muslims set about establishing their own scripture, along with their own salvation history. ${ }^{29}$

Tentu saja banyak sarjana yang menentang kedua kesimpulan di atas -yang berbeda dengan pandangan tradisional --, yang diajukan sarjana Muslim dan non Muslim Barat. ${ }^{30}$ Mayoritas sarjana Barat, sebelum munculnya kedua kesimpulan Burton dan Wansbrough, setuju dengan sumber Muslim tradisional yang menyatakan bahwa al-Qur'an dibukukan pada masa khalifah 'Uthmān. Ini bisa dilihat dari karya Theodore Noldeke dan Friedrich Schwally. Satu lagi tesis tentang sejarah al-Qur'ān yang diajukan sarjana Barat adalah tesis A. Mingana yang mengajukan bahwa edisi resmi al-Qur'ān baru muncul pada masa Abd alMalik ibn Marwan, khalifah kelima dinasti Umayyah, berdasarkan pada sumbersumber Kristen berbahasa Suryani.

Demikianlah pemetaan Sirry terhadap empat tesis yang telah diajukan sarjana Barat terkait sejarah kanonisasi al-Qur'ān: pada masa Nabi Muhammad (Burton), masa khalifah 'Uthman (Noldeke-Schwally), masa Abd al-Malik ibn Marwan (Mingana), dan pada awal abad kesembilan (Wansbrough).

Selain mendiskusikan tentang kapan sebenarnya al-Qur'ān dikanonisasikan, sarjana Barat juga mendiskusikan kapan muṣhaf al-Qur'ān mulai dilengkapi dengan diakritik (titik di atas atau di bawah huruf) dan

${ }^{28}$ Sirry, Kontroversi Islam Awal, 139-140.

${ }^{29}$ Gabriel Said Reynolds, "Introduction: Qur'ānic Studies and Its Controversies," dalam The Qur'ān in Its Historical Context, ed. Gabriel Said Reynolds (London dan New York: Routledge, 2008), 1-25. Penjelasan tentang tesis Wansbrough bisa dilihat di 11-13.

${ }^{30}$ Lihat, Herbert Berg, "The Implications of, and Opposition to, the Methods and Theories of John Wansbrough," Method \& Theory in the Study of Religion 9, 1 (1997): $3-22$. 
harakat. Biasanya umat Islam tidak terlalu membahas atau mempermasalahkan ini, karena mereka sejak awal sudah mendapatkan muṣhaf al-Qur'ān lengkap dengan diakritik dan harakat, yang disebut dalam kajian Barat dengan "scriptio plena.'Padahal, sebelum menjadi “scriptio plena”, teks al-Qur'ān masih berupa "scriptio defectiva," yaitu teks yang terdiri dari huruf-huruf tanpa diakritik dan harakat.

Sirry menunjukkan bahwa al-Qur'ān yang hingga saat ini umat Islam gunakan adalah Edisi Kairo yang terbit pertama kali pada 10 Juli 1924. Edisi ini bertujuan untuk menyeragamkan bacaan al-Qur'ān untuk digunakan di sekolahsekolah di Mesir, karena beragamnya versi al-Qur'ān yang digunakan di sekolah-sekolah. Dengan terbitnya Edisi Kairo ini, yang kemudian direvisi di akhir tahun 1924 dan di tahun 1936, -- yang juga dikenal dengan "Edisi Fārūq" sebagai penghormatan kepada Raja Mesir Fārūq (berkuasa tahun 19361952), ${ }^{31}$ maka "versi-versi lain yang muncul sebelumnya dihancurkan dan dibuang ke Sungai Nil. Demikianlah, tindakan pemerintah Mesir terhadap versiversi al-Qur'an tak ubahnya seperti yang dilakukan Khalifah Usman dan Gubernur Hajjaj, yakni, melarang dan menghancurkan kodeks-kodeks al-Qur'an versi lain." 32

Penyeragaman bacaan al-Qur'ān edisi Kairo yang merujuk pada bacaan Ḥaṣ dari 'Āṣim, menurut Sirry, mengakibatkan bacaan/qirāàt lain, selain Hafṣ, sebagai asing dan tidak mu'tabar. Padahal bacaan Hafs adalah salah satu dari tujuh (ada juga yang mengatakan sepuluh atau empat belas) bacaan yang absah.

Dalam mentransformasikan teks al-Qur'ān dari scriptio defectiva ke scriptio plena, sesuai dengan hasil pembacaan Sirry terhadap beberapa literatur, peran Hajjāj b. Yūsuf (w. 95/714) sangat besar. Iabersama tim khusus dari ulama Basrah, memperkenalkan dan membubuhkan titik (.) ke beberapa huruf yang serupa, seperti ba, ta, dan tha, serta jim dan kha, serta lainnya. Dengan adanya diakritik ini, huruf-huruf hijaiyah bisa dibedakan. ${ }^{33}$

Selain itu, ada juga kontribusi 'Ubayd Allah ibn Ziyad (w. 67/686) yang membubuhkan huruf alif untuk membedakan bacaan panjang dan pendek. Hal ini menunjukkan bahwa muṣhaf al-Qur'ān sebelumnya belum memiliki diakritik titik dan juga alif.

Walaupun penambahan diakritik ini memberikan kemudahan dalam membaca dan membedakan beberapa huruf, beberapa sarjana Barat, seperti Gerd Puin, mencurigai bahkan meyakini bahwa "the medieval Muslim scholars

\footnotetext{
${ }^{31}$ Reynolds, "Introduction: Qur'ānic Studies and Its Controversies,” 2 dst.

${ }^{32}$ Sirry, Kontroversi Islam Awal, 147.

${ }^{33}$ Sirry, Kontroversi Islam Awal, 149.
} 
who established the scriptio plena of the Qur'an misread the scriptio defectiva in numerous places." 34

Puin adalah salah satu sarjana Jerman yang terlibat dalam proyek restorasi manuskrip yang ditemukan di masjid Șan‘à' Yaman, dan telah mengkopi beberapa manuskrip al-Qur'ān yang ditemukan di Yaman. Dengan membandingkan manuskrip kuno dan muṣhaf yang ada saat ini, Puin menunjukkan, misalnya, bahwa huruf a panjang biasanya dituliskan di manuskrip dengan huruf "ya", sehingga bacaan iläh tertulis di manuskrip dengan ilayh. Hal ini kemudian menimbulkan perdebatan apakah seharusnya membaca Ibrāhīm atau Abrahām, dan Shaytān atau Shätānn. ${ }^{35}$

Namun sayangnya manuskrip yang ditemukan di Șan'à', Yaman ini belum banyak dipublikasikan sehingga belum banyak bisa membandingkan antara manuskrip dengan muṣhaf al-Qur'ān yang ada. ${ }^{36}$ Dalam hal ini, Behnam Sadeghi dan Mohsen Goudarzi menyayangkan Puin dan sarjana lainnya yang memiliki microfilm manuskrip-manuskrip Șan'à' Yaman tersebut namun tidak mempublikasikannya. Mereka menulis: "Scholars have not yet been granted access to the microfilms that have been in the possession of Puin and Bothmer, nor has any author travelled to San' $\bar{a}$ ' and published a study using the microfilms or manuscripts there." ${ }^{, 37}$

Tema ketiga yang didiskusikan Sirry dalam bukunya adalah tentang narasi biblikal yang ada dalam al-Qur'ān. Beberapa sarjana Barat pada masa lalu ada yang berkesimpulan bahwa al-Qur'ān dipengaruhi ajaran Yahudi, seperti karya A. Geiger yang berjudul Was hat Mohammed aus dem Judenthume aufgenommen? (1833), atau dipengaruhi ajaran Kristen seperti karya J. Wellhausen Reste Arabischen Heidentums (1897), dan karya-karya sarjana Barat lainnya. Namun, Sirry menegaskan bahwa dalam kesarjanaan Barat kontemporer elemen-elemen biblikal yang ada di dalam al-Qur'ān tidak lagi dipahami sebagai "pengaruh" atau "borrowing." Sirry menyatakan:

"Argumen bahwa al-Qur'an meminjam dari tradisi Yahudi atau Kristen dalam kesarjanaan kontemporer sudah tidak lagi fashionable. Teori "borrowing" (pinjaman) itu sudah banyak ditolak. Dalam kesarjanaan modern, elemen-elemen Biblikal dalam al-Qur'an dimaknai bahwa al-Qur'an berdialog atau

\footnotetext{
${ }^{34}$ Reynolds, "Introduction: Qur’ānic Studies and Its Controversies," 7. Penekanan dengan tulis tebal dari saya.

${ }^{35}$ Reynolds, "Introduction: Qur'anic Studies and Its Controversies," 7. Lihat juga diskusi lebih lanjut karya Puin di Sirry, Kontroversi Islam Awal, 150-151.

${ }^{36}$ Tentang Manuskrip al-Qur'an San'ā' bisa dilihat di Behnam Sadeghi dan Mohsen Goudarzi, "Șan'à' 1 and the Origins of the Qur'àn," Der Islam 87 (2011): 1-129.

${ }^{37}$ Sadeghi dan Goudarzi, "Șan‘à' 1 and the Origins of the Qur'ān," 11.
} 
berinteraksi secara kreatif dengan tradisi agama-agama monoteis sebelumnya, utamanya Yahudi dan Kristen."38

Beberapa sarjana Barat yang mengkaji narasi biblikal di dalam al-Qur'ān dengan pendekatan dialogis ini misalnya Angelika Neuwirth, yang bisa dilihat dari kumpulan tulisannya di buku Scripture, Poetry, and the Making of a Community: Reading the Qur'an as a Literary Text, ${ }^{39}$ khususnya di Bagian Ketiga yang membandingkan narasi-narasi biblikal antara Bibel dan al-Qur'ān.

Tema yang lain yang didiskusikan Sirry dalam bukunya adalah tentang asbāb al-nuzūl. Bagi saya agak out of context membahas asbāb al-nuzūl dalam konteks sejarah al-Qur'ān pada masa Islam Awal. Saya lebih setuju jika pembahasannya adalah tentang literatur tafsirpada masa formatif, karena salah satu yang menjadi kajian Wansbrough dalam karyanya Quranic Studies adalah tafsir. Bahkan Andrew Rippin harus mengingatkan para sarjana Barat bahwa karya Wansbrough tidak hanya mendiskusikan tentang "the origins of the Qur'ān" akan tetapi juga tentang tafsīr, yang dibahas Wansbrough secara spesifik di Bagian Keempat. ${ }^{40}$

Memang Rippin termasuk salah satu yang banyak mengelaborasi tesis Wansbrough dan mendiskusikan tentang teks-teks tafsir awal, dengan mengkritisi kesimpulan F. Sezgin, dan juga karya Issa J. Boullata dan C.H.M. Versteegh - secara berurutan -- tentang tafsīi Ibn 'Abbās Masā'il Näfi' ibn alAzraq dan Arabic Grammer and Qur'anic Exegesis in Early Islam. ${ }^{41}$

Argumentasi Rippin - yang diambil dari Wansbrough - adalah perlunya "textual evidence for historical claims." ${ }^{42}$ Wansbrough dan Rippin mendapatkan banyaknya klaim-klaim yang diajukan para mufassir di abad kedua dan ketiga hijriah yang merujuk pendapat ulama sebelumnya dan bahkan menisbatkan suatu karya tafsir kepada mufassir awal,namun tidak didukung dengan bukti tekstual. Di samping itu, mereka juga mendapatkan banyaknya manuskrip yang "misidentified"(salah diidentifikasi).

\footnotetext{
${ }^{38}$ Sirry, Kontroversi Islam Awal, 157.
}

${ }^{39}$ Angelika Neuwirth, Scripture, Poetry, and the Making of a Community: Reading the Qur'an as a Literary Text (London: Oxford University Press, in association with the Institute of Ismaili Studies, 2014). Lebih lengkap contoh-contoh kajian sarjana Barat dalam konteks ini, lihat Sirry, Kontroversi Islam Awal, 159 dst.

${ }^{40}$ Andrew Rippin, "Quranic Studies, Part IV: Some Methodological Notes," Method\& Theory in the Study of Religion 9, 1 (1997): 39-46.

${ }^{41}$ Lihat artikel-artikel Rippin dan juga artikel-artikel lainnya terkait dengan kajian teks tafsìr awal di Shah, Tafsir: Interpreting the Qur'ān, terutama di Bagian Kedua "Early Exegetical Texts."

${ }^{42}$ Rippin, “Quranic Studies, Part IV,” 41. 
Sezgin, misalnya, berkeyakinan bahwa Ibn 'Abbās, sebagai turjumān alQur'ān, juga mengarang buku tafsir, karena ia banyak dirujuk oleh muridmuridnya. Wansbrough dalam hal ini tidak menerima pernyataan kalau hanya didasarkan dengan rujukan (ascription) para mufassir. Apalagi posisi sentral Ibn 'Abbās membuatnya menjadi primadona untuk selalu dijadikan rujukan, dengan tujuan untuk lebih memberikan legitimasi pada penafsirannya. Rippin juga telah membuktikan berdasarkan kajian dan surveinya terhadap manuskrip-manuskrip yang ada bahwa banyak manuskrip yang salah diidentifikasi sebagai karangan Ibn 'Abbās." 43

Selain argumen "textual evidence," Wanbrough juga telah mengajukan beberapa kriteria stilistik dan fungsional untuk menentukan perkembangan tafsī, yang berawal dari tafsì haggadik/naratif, halakhik/hukum, masoretik/tekstual-gramatikal, retorik, dan alegorik. Dengan urutan kronologis seperti ini bisa dikatakan bahwa "semakin kompleks ekspresi suatu tafsir maka semakin akhir penanggalan tafsī tersebut." Dengan kriteria semacam ini, Wansbrough dan Rippin tidak bisa menerima keberadaan kutipan-kutipan puisi dalam tafsì masa formatif, karena kutipan puisi merupakan kriteria stilistik tafsīr retorik.

Demikianlah beberapa perdebatan tentang tafsï pada masa Islam Awal, yang sayangnya tidak dibahas dalam buku Sirry. Kajian sarjana Barat dalam bidang tafsir awal "early tafsir" tampaknya tidak sekaya kajian mereka terhadap sejarah pembentukan al-Qur'ān. Mungkin karena tidak banyak manuskrip tafsìr masa Islam Awal yang ditemukan dan dipublikasikan. Penemuan dan publikasi manuskrip tafsir masa formatif akan lebih memperkaya wawasan kita tentang tafsir pada masa Islam Awal.

\section{Penutup}

Walaupun Sirry tidak mendiskusikan tema tafsir pada masa Islam Awal, yang tentu saja didasarkan pada alasan-alasan akademis, secara keseluruhan karya Sirry ini sangat penting, karena ia telah membukakan mata kita atas kekayaan kesarjanaan Barat dalam kajian Islam, dalam hal ini Islam Awal, (dalam tulisan ini lebih difokuskan lagi pada al-Qur'ān pada masa formatif). Tidak saja kajian mereka meliputi tema-tema yang krusial - tema yang kebanyakan Muslim telah menerimanya taken for granted --, tapi juga telah

${ }^{43}$ Lihat misalnya, Rippin, "Ibn 'Abbās's Al-Lughāt fí al-Qur'ān," Bulletin of the School of Oriental and African Studies 44, 1 (1981): 15-25, dan idem, "Ibn 'Abbās's Gharib al-Qur'an," Bulletin of the School of Oriental and African Studies 46, 2 (1983): 332-333. 
menghasilkan tesis dan teori yang berbeda-beda, bahkan bertentangan. Tesis mereka, sebagaimana yang telah ditunjukkan Sirry, berawal dari bagaimana mereka mendekati dan menyikapi sumber-sumber tradisional Muslim "yang bermasalah."

Sarjana Muslim - termasuk sarjana Muslim Indonesia - belum banyak terlibat dalam kajian Islam Awal ini. Hal ini, menurut Sirry, dikarenakan "bagi kaum Muslim, al-Qur'ān (dan juga tema Islam Awal, seperti biografi Nabi) merupakan sumber moral dan keagamaan," sementara bagi sarjana Barat, kajian terhadap Islam Awal untuk kepentingan penelitian historis. Akan tetapi mudahmudahan kesimpulan Prof. Donner bahwa seorang beriman (seorang Muslim) tidak bisa menjadi sejarawan Islam Awal bisa terbantahkan dengan munculnya kajian sarjana-sarjana Muslim dalam disiplin ini, seperti yang telah dilakukan Sirry dalam beberapa karya-karyanya.

\section{Daftar Pustaka}

Amal, Taufik Adnan. Rekonstruksi Sejarah Al-Qur'an Yogyakarta: Forum Kajian Budaya dan Agama (FKBA), 2001.

Arif, Syamsuddin. Orientalis \& Diabolisme Pemikiran. Jakarta: GIP, 2008.

-------. "The Challenge of Orientalist in Islamic Thought." Presentasi di the International Institute of Islamic Thought and Civilization bulan Mei 2010 yang juga bisa diakses di youtube https://www.youtube.com/watch?v=QZW7Z1UH7L0.

Armas, Adnin. "Orientalis dan Studi Alquran.” Republika 14 April 2005.

-----. "Selamat Datang Profesor Azami!.” Republika 30 March 2005.

Donner, Fred. "The Historian, the Believer, and the Qur'ān." Dalam New Perspectives on the Qur'ān. Ed. Gabriel Said Reynolds. London: Routledge, 2011.

. Narratives of Islamic Origins: The Beginnings of Islamic Historical Writing. Princeton, NJ: The Darwin Press, 1998.

Manzoor, Parvez. "Method Against Truth: Orientalism and Qur'anic Studies." Muslim World Book Review 7 (1987), 33-49. Dicetak ulang di Andrew Rippin (ed.). The Qur'an: Style and Content. Aldershot, Singapore, Sydney: Ashgate Variorum, 2001, 381-397.

Neuwirth, Angelika. Scripture, Poetry, and the Making of a Community: Reading the Qur'an as a Literary Text. London: Oxford University Press, in association with the Institute of Ismaili Studies, 2014. 
Reynolds, Gabriel Said. “Introduction: Qur'ānic Studies and Its Controversies." Dalam The Qur'ān in Its Historical Context. Ed. Gabriel Said Reynolds. London dan New York: Routledge, 2008, 1-25.

Rippin, Andrew. "Ibn 'Abbās's Gharīb al-Qur'ān." Bulletin of the School of Oriental and African Studies 46, 2 (1983): 332-333.

-------. "Ibn 'Abbās's Al-Lughät fí al-Qur'ān." Bulletin of the School of Oriental and African Studies 44, 1 (1981): 15-25.

-------. "Quranic Studies, Part IV: Some Methodological Notes." Method \& Theory in the Study of Religion 9, 1 (1997): 39-46.

Sadeghi, Behnam dan Mohsen Goudarzi. "Șan‘à' 1 and the Origins of the Qur'ān.” Der Islam 87 (2011): 1-129.

Shah, Mustafa. Tafsir: Interpreting the Qur'ān. London dan New York: Routledge, 2013. 4 jilid.

Sirry, Mun'im. "The Early Development of the Quranic Hanif." Journal of Semitic Studies LVI, 2 (Autumn 2011): 345-366.

-------. "Rekonstruksi Sejarah Teks Alquran.” Republika 1 April 2005.

-------. Kontroversi Islam Awal: Antara Mazhab Tradisionalis dan Revisionis. Bandung: Mizan, 2015.

-------. Polemik Kitab Suci: Tafsir Reformis atas Kritik Al-Qur'an terhadap Agama Lain. Jakarta: Gramedia, 2013.

Turner, Colin. The Koran: Critical Concepts in Islamic Studies. London dan New York: Routledge, 2004. 4 julid.

Zarkasyi, Hamid Fahmi. "Worlview Islam dan Kapitalisme Barat." Jurnal Tsaqafah 9, 1 (2013): 15-36. 